Rafael Silva Pereira

\title{
A Cloud based Real-Time Collaborative Filtering Architecture for Short-Lived Video Recommendations
}

\section{TESE DE DOUTORADO}

DEPARTAMENTO DE INFORMÁTICA

Programa de Pós-Graduação em Informática 


\section{Pontifícia U Universidade $C_{\text {atólLa }}$ DO RIO DE JANEIRO}

Rafael Silva Pereira

\section{A Cloud based Real-Time Collaborative Filtering Architecture for Short-Lived Video Recommendations}

\section{TESE DE DOUTORADO}

Thesis presented to the Programa de Pós-Graduação em Informática of the Departamento de Informática, PUC-Rio as partial fulfillment of the requirements for the degree of Doutor em Ciências - Informática

Advisor: Prof. Hélio Côrtes Vieira Lopes 
Rafael Silva Pereira

\title{
A Cloud based Real-Time Collaborative Filtering Architecture for Short-Lived Video Recommendations
}

Thesis presented to the Programa de Pós-Graduação em Informática, of the Departamento de Informática do Centro Técnico Científico da PUC-Rio, as partial fulfillment of the requirements for the degree of Doutor.

\author{
Prof. Hélio Côrtes Vieira Lopes \\ Advisor \\ Departamento de Informática - PUC-Rio \\ Prof. Marco Antonio Casanova \\ Departamento de Informática - PUC-Rio \\ Profa. Karin Koogan Breitman \\ EMC \\ Profa. Giseli Rabello Lopes \\ UFRJ \\ Prof. José Viterbo Filho \\ UFF
}

Prof. Marcus Vinicius Soledade Poggi de Aragão

Departamento de Informática - PUC-Rio

Prof. Luiz André Portes Paes Leme

UFF

Prof. Márcio da Silveira Carvalho Coordinator of the Centro Técnico Científico - PUC-Rio 
All rights reserved

\section{Rafael Silva Pereira}

Graduated in Electronics and Computer Engineering at Universidade Federal do Rio de Janeiro - UFRJ in 2006. Masters in Computer Science at Pontifícia Universidade Católica do Rio de Janeiro - PUCRio in 2011, and Engineering Manager from Globo.com since 2006.

Bibliographic data

Pereira, Rafael Silva

A Cloud based Real-Time Collaborative Filtering Architecture for Short-Lived Video Recommendations / Rafael Silva Pereira ; advisor: Hélio Côrtes Vieira Lopes. - 2015.

86 f. : il. (color.) ; $30 \mathrm{~cm}$

Tese (doutorado)-Pontifícia Universidade Católica do Rio de Janeiro, Departamento de Informática, 2015.

Inclui bibliografia

1. Informática - Teses. 2. Computação na nuvem. 3. Filtragem colaborativa. 4. Recomendação. 5. Sistemas distribuídos. 6. Arquiteturas orientadas a serviços. I. Lopes, Hélio Côrtes Vieira. II. Pontifícia Universidade Católica do Rio de Janeiro. Departamento de Informática. III. Título.

CDD: 004 


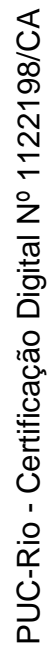

To my parents and my wife, for your unconditional love and support 


\section{Acknowledgements}

First of all, to my family, specially my parents that offered me all the support and encouragement to always continue independently of the obstacles, and to afford all my primary education. To my wife Sofia Gross, that always supported me in this journey since the beginning, even in the moments where all my attention was directed to this work.

To my advisor Prof. Hélio Lopes for its kindness and for the constant support and technical knowledge, always available when necessary. To all professors of the Department of Informatics from PUC-Rio for their knowledge and help, especially to Karin Breitman who was my advisor during my Masters at PUC-Rio, and is who encourage me to start this work. I also thank Professor Simone Barbosa who helped me to solve the issues with my registration during the course. To all my colleagues from PUC-Rio.

To the professors responsible for the evaluation of this work, for your availability and dedication reading and contributing to this research.

To Globo.com, my employer, that paid all expenses of this Doctoral course and gave me all resources needed for this research.

Finally, to Brazilian Government, for its public, high quality, and free federally funded higher education system, that allowed me to complete my graduation degree. 


\section{Abstract}

Pereira, Rafael Silva; Lopes, Hélio Côrtes Vieira (Advisor). A Cloud based Real-Time Collaborative Filtering Architecture for Short-Lived Video Recommendations. Rio de Janeiro, 2015. 86p. DSc. Dissertation Departamento de Informática, Pontifícia Universidade Católica do Rio de Janeiro.

This dissertation argues that the combination of collaborative filtering techniques, particularly for item-item recommendations, with emergent cloud computing technology can drastically improve algorithm efficiency, particularly in situations where the number of items and users scales up to several million objects. It introduces a real-time item-item recommendation architecture, which rationalizes the use of resources by exploring on-demand computing. The proposed architecture provides a real-time solution for computing online item similarity, without having to resort to either model simplification or the use of input data sampling. This dissertation also presents a new adaptive model for implicit user feedback for short videos, and describes how this architecture was used in a large scale implementation of a video recommendation system in use by the largest media group in Latin America, presenting results from a real life case study to show that it is possible to greatly reduce recommendation times (and overall financial costs) by using dynamic resource provisioning in the Cloud. It discusses the implementation in detail, in particular the design of cloud based features. Finally, it also presents potential research opportunities that arise from this paradigm shift.

\section{Keywords}

Cloud Computing; Recommendations; Collaborative Filtering; Distributed Systems; Service Oriented Architectures. 


\section{Resumo}

Pereira, Rafael Silva; Lopes, Hélio Côrtes Vieira (Orientador). Uma Arquitetura de Filtragem Colaborativa em Tempo Real Baseada em Nuvem para Recomendação de Vídeos Efêmeros. Rio de Janeiro, 2015. 86p. Tese de Doutorado - Departamento de Informática, Pontifícia Universidade Católica do Rio de Janeiro.

Esta tese propõe que a combinação de técnicas de filtragem colaborativa, em particular para recomendações item-item, com novas tecnologias de computação em nuvem, pode melhorar drasticamente a eficiência dos sistemas de recomendação, particularmente em situações em que o número de itens e usuários supera milhões de objetos. Nela apresentamos uma arquitetura de recomendação item-item em tempo real, que racionaliza o uso dos recursos computacionais através da computação sob demanda. A arquitetura proposta oferece uma solução para o cálculo de similaridade entre itens em tempo real, sem ter que recorrer à simplificação do modelo de recomendação ou o uso de amostragem de dados de entrada. Esta tese também apresenta um novo modelo de feedback implícito para vídeos de curta duração, que se adapta ao comportamento dos usuários, e descreve como essa arquitetura foi usada na implementação de um sistema de recomendação de vídeo em uso pelo maior grupo de mídia da América Latina, apresentando resultados de um estudo de caso real para mostrar que é possível reduzir drasticamente o tempo de cálculo das recomendações (e os custos financeiros globais) usando o provisionamento dinâmico de recursos na nuvem. Ela discute ainda a implementação em detalhes, em particular o projeto da arquitetura baseada em nuvem. Finalmente, ela também apresenta oportunidades de pesquisa em potencial que surgem a partir desta mudança de paradigma.

\section{Palavras-chave}

Computação na Nuvem; Filtragem Colaborativa; Recomendação; Sistemas Distribuídos; Arquiteturas Orientadas à Serviço. 


\section{Table of Contents}

1 Introduction 13

1.1. Goals 15

1.2. Main Contributions 16

1.3. Related Work 16

$\begin{array}{lr}\text { 1.4. Outline } & 18\end{array}$

2 Background 19

2.1. Recommender Systems 19

2.1.1. The Recommendation Problem 20

2.1.2. Recommendation Strategies 23

2.1.3. Limitations of Collaborative Filtering 29

2.1.4. Comparison of Strategies 30

2.2. Cloud Computing 31

2.2.1. Cloud Computing Paradigms 32

2.2.2. Amazon Web Services Platform 35

3 Large Scale Video Recommendations 40

3.1. Introduction 40

3.2. Item-Item Video Recommendations $\quad 41$

4 A Real-Time Large Scale Collaborative Filtering Architecture 48

4.1. A multi-layered architecture $\quad 50$

4.1.1. The first layer - Hits Layer $\quad 51$

4.1.2. The second layer - Persistence Layer 52

4.1.3. The third layer - Similarity Layer 55

5 An Adaptive Implicit Feedback Model $\quad 57$

6 Implementation and Deploy 65

6.1. Implementation Issues $\quad 65$

6.2. Deploy using Amazon Web Services 67 
7 Application in Globo.com and Results

8 Conclusions $\quad 78$

9 References 


\section{List of Figures}

Figure 1 - Recommendation Process 20

Figure 2 - Collaborative Filtering process $\quad 25$

Figure 3 - Collaborative Filtering results in Amazon.com 26

Figure 4 - Neighborhood training process 26

Figure 5 - Item-based collaborative filtering 27

Figure 6 - Netflix Star Ratings for explicit feedback 41

Figure 7 - YouTube "Thumbs up" / "Thumbs Down" explicit feedback 42

Figure 8 - Similarity recalculation process for a single piece of feedback 44

Figure 9 - Video views from 5 news videos from the Jornal Nacional $\quad 45$

Figure 10 - Multi-layer collaborative filtering process 51

Figure 11 - Player sending the HTTP call informing that an user started to watch a video 52

Figure 12 - Layer II storing binary feedback in sets 53

Figure 13 - Layer II storing items already evaluated by the user in a supporting set structure

Figure 14 - Similarity calculation between items $I_{1}$ and $I_{2}$ through intersection of sets 55

Figure 15 - Completion ratio by category of short videos and clips $\quad 58$

Figure 16 - Consumption pattern of short videos of the National

Journal compared the the average of its category

Figure 17 - Video $A$ and video $B$ have different consumption curves and hence different feedback scales 61

Figure 18 - Adapted feedback scales for videos A and B 62

Figure 19 - Redis pools connecting architecture layers 66

Figure 20 - The recommendation platform deployed on AWS 68

Figure 21 - Recommendations integrated in the player and presented at the end of the playback $\quad 70$

Figure 22 - Recommendations integrated in the web page $\quad 70$

Figure 23 - User feedback requests for a 10 day period starting on Monday 
Figure 24 - Variation in number of Layer II nodes according to Queue I size

Figure 25 - Processing Time in Layer II vs. Total Unique Users

Figure 26 - Variation in number of Layer III nodes according to Queue II size 73

Figure 27 - Persistence Redis pool configuration $\quad 75$

Figure 28 - Conversion rate comparison 76 


\section{List of Tables}

Table 1 - Rating Matrix for movies

Table 2 - Total monthly cost for Globo.com recommendations deployment 